\title{
A first record of Stylops melittae Kirby, 1802 (Insecta: Strepsiptera: Stylopidae) in Belarus
}

\section{Первая находка Stylops melittae Kirby, 1802 (Insecta: Strepsiptera: Stylopidae) в Беларуси}

\author{
A.M. Ostrovsky \\ А.М. Островский
}

Gomel State Medical University, Lange Str. 5, Gomel 246000 Belarus. E-mail: Arti301989@mail.ru. Гомельский государственный медицинский университет, ул. Ланге 5, Гомель 246000 Беларусь.

Key words: Stylops melittae, fauna, Belarus.

Ключевые слова: Stylops melittae, фаунистика, Беларусь.

\begin{abstract}
Stylops melittae Kirby, 1802 (Strepsiptera: Stylopidae) is firstly recorded in Gomel Region of Belarus near Uza village as a parasite of bee Andrena (Taeniandrena) ovatula (Kirby, 1802) in spring 2016. Brief information on distribution and ecology of the species is given.
\end{abstract}

Резюме. Веерокрылое Stylops melittae Kirby, 1802, вид из семейства Stylopidae, найденный в Гомельской области в окрестностях деревни Уза на Andrena (Taeniandrena) ovatula (Kirby, 1802) весной 2016 года, впервые отмечен для фауны Беларуси. Приведены данные по распространению и экологии вида.

\section{Introduction}

Members of the order Strepsiptera display highly peculiar morphology and lifestyles. They are small to medium sized insects (1.0-7.5 mm long) exhibiting extreme sexual dimorphism [Kinzelbach, 1971; Kathirithamby, 1989]. Free living and flying males have twisted hind wings, while their fore wings are reduced to clublike appendages. Usually endoparasitic and wingless females are known to colonize members of seven insect orders [Kathirithamby, 1989, 2009]. Approximately 600 Strepsiptera species are known to exist globally [Kathirithamby, 2002; Kinzelbach, Pohl, 2003], while 30 species from 7 families are known in Europe [Pohl, 2010; Soon et al., 2011].

The order Strepsiptera in Belarus hasn't been studied, data on the record of one species Stenocranophilus anomalocerus Pierce, 1918 from the family Halictophagidae, parasitoid of Liburnia Stel, 1866 (Hemiptera: Delphacidae), has been published previously [Medvedev, 1965]. Continuing the research, Stylops melittae Kirby, 1802 has been found in Belarus. Both the genus Stylops Kirby, 1802 and the family
Stylopidae Kirby, 1913 are cosmopolitan [Kathirithamby, 1989].

\section{Results}

\author{
Strepsiptera \\ Stylopidae Kirby, 1913 \\ Stylops melittae Kirby, 1802 \\ Fig. 1.
}

Material. Republic of Belarus, Gomel Area, near Uza village, 14.05.2016, A.M. Ostrovsky leg. et det. $-10^{7}$ of Andrena (Taeniandrena) ovatula (Kirby, 1802) stylopized by female of S. melittae.

Distribution. Widely distributed in Europe and extending to the Near East and North Africa, currently known from Austria, Belgium, Bosnia and Herzegovina, Bulgaria, Canary Islands, Croatia, Cyprus, Czech Republic, Danish mainland, Estonia, Finland, French mainland, Germany, Great Britain, Greek mainland, Hungary, Italian mainland, Macedonia, Montenegro, Northwest European Russia, Norwegian mainland, Poland, Portuguese mainland, Serbia, Slovakia, Slovenia, Spanish mainland, Sweden, Switzerland, The Netherlands [Pohl, 2010; Soon et al., 2012].

S. melittae is a typical parasite of many Andrena Fabricius, 1775 (Hymenoptera: Apidae) species [Kinzelbach, 1978; Kathirithamby, 1989]. However, from Belarus only $A$. (T.) ovatula has been recorded as its host. In Belarus $A$. (T.) ovatula is a widespread and common species.

\section{Conclusion}

The family, genus and species are formally new to Belorussia's list of Strepsiptera: Stylopidae, Stylops Kirby, 1802, and Stylops melittae Kirby, 1802. From Belarus only $A$. (T.) ovatula has been recorded as its host of $S$. melittae. 

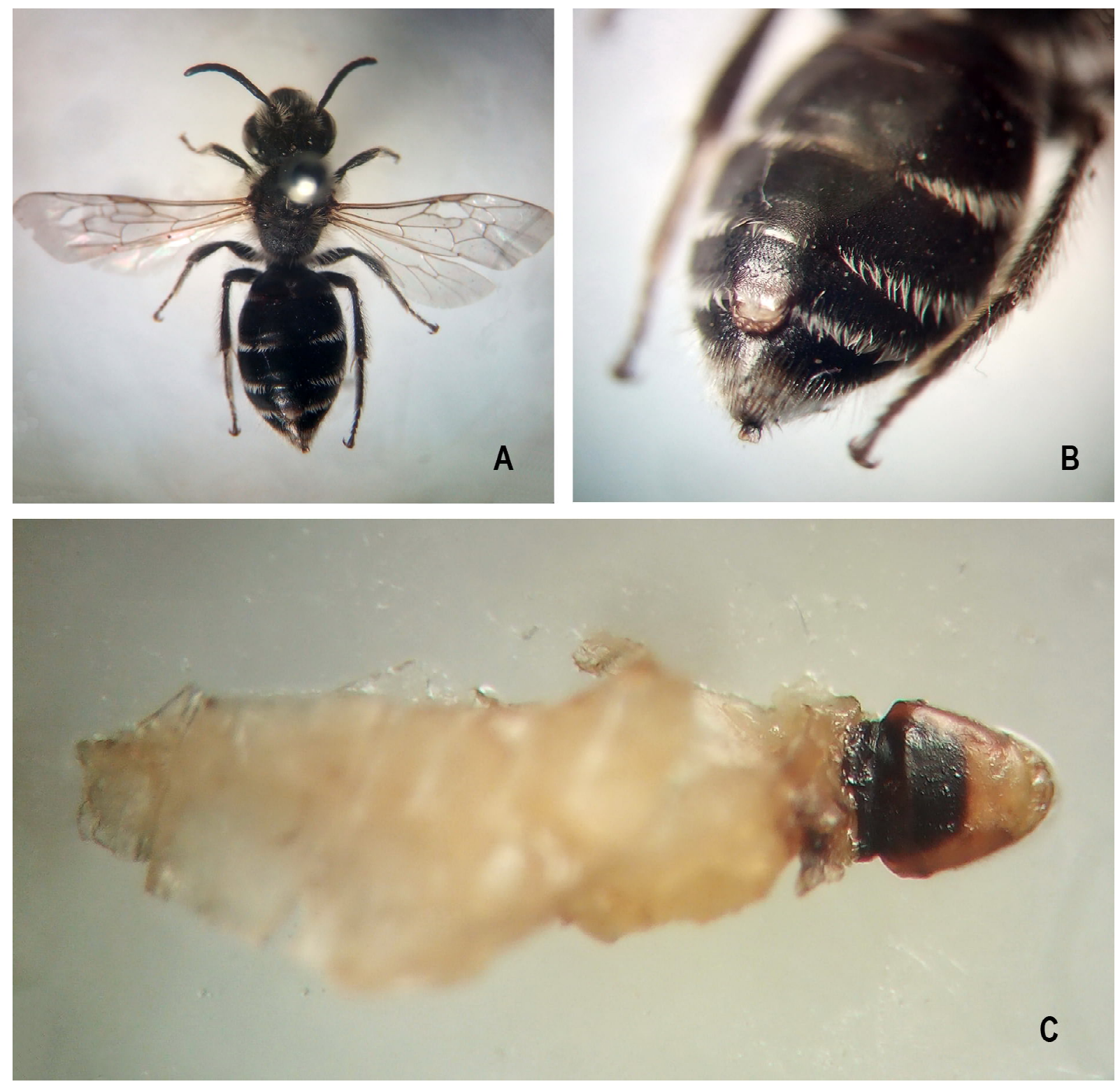

Fig. 1. A, B - Andrena (Taeniandrena) ovatula (Kirby, 1802): specimen (male) stylopized by a female of Stylops melittae Kirby, 1802; C - S. melittae, female.

Рис. 1. А, В - Andrena (Taeniandrena) ovatula (Kirby, 1802): экземпляр (самец), стилопизированный самкой Stylops melittae Kirby, 1802; C - S. melittae, самка.

\section{References}

Kathirithamby J. 1989. Review of the Order Strepsiptera // Systematic Entomology. Vol.14. P.41-92.

Kathirithamby J. 2002. Strepsiptera. Twisted-wing parasites. Version 24 September 2002 (under construction). - The Tree of LifeWeb Project. Available at http://tolweb.org/ Strepsiptera/8222/2002.09.24 (accessed 15 March, 2018).

Kathirithamby J. 2009. Host-Parasitoid Associations in Strepsiptera // Annual Review of Entomology. Vol.54. P.227-249.

Kinzelbach R.K. 1971. Morphologische Befunde an Fächerflüglern und ihre phylogenetische Bedeutung (Insecta: Strepsiptera) // Zoologica. H.119. S.1-256.
Kinzelbach R.K., Pohl H. 2003. Ordnung Strepsiptera, Fächerflüger // Wirbellose Tiere. 5. Teil: Insecta. Heidelberg-Berlin: Spektrum Akademischer Verlag. S.526-539.

Medvedev L.N. 1965. [The order Strepsiptera] // Keys to the insects of the European part of the USSR. Coleoptera and Strepsiptera. M.-L.: Nauka Publ. Vol.2. P.641-645 [In Russian].

Pohl H. 2010. Fauna Europaea: Strepsiptera. Fauna Europaea, ver. 2.4. Available at http://www.faunaeur.org (accessed 15 March, 2018).

Soon V., Kesküla T., Kurina O. 2011. Strepsiptera species in Estonia // Entomologica Fennica. Vol.25. P.213-218. 